\title{
Sciendo
}

Administration, vol. 68, no. 4 (2020), pp. 97-119

doi: 10.2478/admin-2020-0026

\section{The reform of human resource management in the Irish public service}

\author{
William K. Roche \\ College of Business, University College Dublin, Ireland
}

Joanna O'Riordan

Institute of Public Administration, Ireland

\begin{abstract}
This paper reviews human resource management (HRM) reforms in the Irish public service over the past twenty-five years. The narrative is based around five HRM themes which have been the main focus of public service reform efforts: performance management, public service careers, leadership, strategic HRM and employment relations. The paper examines all available independent empirical research as well as internal and external reviews commissioned by the public service. The paper contributes to the empirical literature on HRM in the public service and in Ireland, and locates the pattern of HRM reform in the public service in Ireland in comparative context. The paper concludes by noting that while progress has been made, further energy is required in respect of HRM reform.
\end{abstract}

Keywords: Human resource management, Ireland, public service, reform 


\section{Introduction}

The last twenty-five years have witnessed the most sustained and significant attempts to reform human resource management (HRM) in the history of the Irish public service. Two HRM reform cycles were evident over the period. The first of these was influenced by the Strategic Management Initiative (SMI) and spanned the period from 1994 to 2008. The second reform cycle, which provides the main focus of this paper, began as a response to a fiscal crisis and continued during increasingly positive fiscal conditions up to early 2020. This paper reviews and assesses HRM reforms, including public service reforms affecting relations with unions and pay fixing, undertaken during the second reform cycle.

Outlines of areas of reform since 2009 begin with a summary of developments under the SMI reform cycle over the period from 1996 to 2008. In some areas SMI reforms were the direct precursors of postcrisis reforms. Earlier reforms also provide a context and useful point of comparison with reforms over the period since 2009. The concluding section of the paper presents an assessment of the changes and reforms undertaken from 2008 to the early months of 2020 and outlines some possible lines of development following the Covid-19 crisis.

We begin by outlining reforms in different areas of HRM and we then consider changes in employment relations, including pay fixing or pay determination. Where relevant, SMI cycle reforms are first summarised before focusing on post-2008 reforms.

Ireland's public service is rooted historically in the Westminster model, involving a politically neutral civil and public service, staffed in the main by career public servants. Over the period covered by this review the scale of public service employment alternated significantly from over 215,000 employees in the mid 1990s to just over 325,000 at the outset of the Great Recession and fiscal crisis in 2008. Numbers employed fell back to 292,000 in 2013, recovering sharply to over 339,000 in 2019 (Department of Public Expenditure and Reform, n.d.). These changes in employment reflected major shifts in fiscal conditions. As the Irish economy revived and then grew dramatically from the middle of the 1990s, large current budget surpluses were recorded, as Ireland's public debt relative to GDP became one of the lowest in the EU. With the advent of the fiscal crisis, the budget deficit plunged to in excess of 30 per cent in 2010 as the domestic banks were recapitalised and unemployment soared. Public debt reached a peak 
of nearly 124 per cent in 2013. Fiscal conditions recovered up to the Covid-19 pandemic, with a return to modest budget surpluses and a public debt level of around 58 per cent of GDP in 2019. ${ }^{1}$

\section{Performance management}

The SMI was strongly influenced by the internationally prominent 'New Public Management' (NPM) paradigm, which sought to guide public service delivery through clearly defined missions, objectives and priorities, promote accountability for performance, deploy market or market-like mechanisms, and import private sector management techniques into the public service (Pollitt \& Bouckaert, 2017, ch. 1). The SMI's foundation document, Delivering Better Government (Government of Ireland, 1996), recognised the importance of changes in HRM for the overall success of the reform programme (Boyle, 1997, p. 51) and triggered a series of HR reforms. The first performance management system of wide prevalence and durability, the Performance Management and Development System (PMDS), was instituted in the civil service in 2000 and was intended to provide a framework for similar initiatives in other areas of the public service. Though carefully planned and following principles widely applied in the private sector, the PMDS soon proved problematic in practice. Data on performance ratings in the civil service across the 1-5 performance ratings scale revealed a systematic pattern of restriction of range around the midpoints of the scale and showed evidence of leniency: only tiny fractions of public servants were rated as performing in an 'unacceptable' manner. Despite a number of changes made to improve the operation of the system on foot of external evaluation (Mercer Human Resource Consulting, 2004), problems persisted and over time the PMDS became subject to ratings drift as the proportions obtaining higher ratings on the scale drifted upwards (Comptroller and Auditor General, 2010, ch. 10). From 2005 revised arrangements provided for individual performance to be linked with the awarding of pay increments, eligibility for promotion and advancement to higher scales within existing grades - a minimum rating of 'needs improvement' becoming the requisite for progression in these areas. However, no robust procedure existed for managing chronic underperformance (Department of Finance, 2010a, 2010b).

${ }^{1}$ All data on the public finances were obtained from issues of the Economic and Social Research Institute's Quarterly Economic Commentary. 
If the effectiveness of the PMDS system appeared limited in major respects, the same held for the coupling of performance management with performance-related pay that was introduced from 2002 for senior civil and public servants (other than secretaries general). While those covered by the scheme were reported to be satisfied with how it operated, restriction of range was again evident: most covered public servants achieved bonuses which were very often in the middle range of those available. The view developed that in practice bonuses were awarded in recognition of hard work and dedication. Performance objectives were not uncommonly agreed mid-way through performance cycles and the operation of the system was opaque. ${ }^{2}$ The performance-related pay system for senior grades was halted in budgetary cuts introduced in 2009 .

Following the advent of the fiscal crisis, the objective of improving the effectiveness of performance management was stressed in yet more assessments of the PMDS and was centre place in a succession of new civil and public service reform strategies and associated statements of HRM strategy (Department of Finance, 2010a, 2010b; Department of Public Expenditure and Reform, 2011, 2014a, 2014b, 2017a, 2017b). Attempts to inject greater rigour into performance management led to a change in the rating required to receive an incremental pay rise and to be considered for promotion, from 'needs to improve' to 'fully achieved expectations'. A new procedure for managing underperformance was introduced in the civil service, involving personal improvement plans. In the event of continuing underperformance provision was made for triggering the disciplinary procedure, potentially resulting in dismissal (Department of Public Expenditure and Reform, 2016). In 2016 the five-point PMDS rating scale was replaced by a binary scale that rates performance as 'satisfactory' or 'unsatisfactory'. The change was introduced in an attempt to refocus dialogue about performance away from past performance towards identifying goals for the coming year and supporting ways of improving future performance and development.

Notwithstanding continuing changes and tweaks to PMDS, old shortcomings remained. Range restrictions continued to be evident,

\footnotetext{
${ }^{2}$ See, for example, annual reports of the Committee for Performance Awards for the Civil Service, Garda Síochána and Defence Forces for 2002-7; Industrial Relations News, 7 November 2007; Review Body on Higher Remuneration in the Public Sector (2007, chs 18-19).
} 
with fractions of 1 per cent of civil servants rated as having unsatisfactory performance under the revised binary scale. ${ }^{3}$ Reflecting continuing concern at senior management level with the efficacy of performance management, the secretary general of the Department of Public Expenditure and Reform (DPER) was reported as being highly critical of PMDS results for 2018, commenting that the incidence of underperformers was not in keeping with what would be expected in an organisation the size of the civil service. ${ }^{4}$ The same report cited an external study commissioned by the department which found that many of the civil servants surveyed regarded PMDS as a 'box ticking exercise that failed in its objectives to increase performance and support career development'. Managers were also reported as remaining reluctant to deal with underperformance. Civil service engagement surveys conducted in 2015 and 2017 identified similar views of the PMDS system (DCU Business School and Department of Public Expenditure and Reform, 2017). In some respects, the problems with the operation of PMDS in its various guises reflect wider international experience with classical performance management systems in both private and public sector organisations (Cappelli \& Tavis, 2016; Murphy, 2020). Reflecting growing international disillusionment with performance management systems, some critics of the PMDS system have called for radical changes - in particular, the decentralisation of how performance management is conducted - and for experimentation with different approaches (Boyle, 2014).

In line with a commitment made in the Civil Service Renewal Plan (Department of Public Expenditure and Reform, 2014a), performance assessment for secretaries general and grades immediately below was introduced in 2016. To avoid politicising the work of top-level civil servants by providing for ministerial assessment, a three-person performance review group assesses performance. The group comprises the secretaries general of DPER, the Department of the Taoiseach and the government, and an external member. It was anticipated that the Performance Review Group would report to the Civil Service Accountability Board, which would produce an annual report reflecting its assessment of the effectiveness of the system (Civil Service Accountability Board, 2016). However, the Accountability

${ }^{3}$ Department of Public Expenditure and Reform reports on PMDS in the civil service.

${ }^{4}$ Industrial Relations News, 6 February 2020. 
Board has effectively been disbanded and little is yet publicly known about the operation of the new system. 5

\section{Public service careers}

A 'career-based' public service was retained under the SMI reform cycle. However, 'position-based' appointments became more prevalent as numbers of fixed-term appointments increased, especially in areas and occupations where skills shortages occurred. Within a decade the public service career system was seen to have become more open, but for external observers the changes revealed no sign of 'systematic deliberations or systematic strategies' (OECD, 2008, p. 112). Public service careers progressed within 'silos' characterised by limited mobility across departments or areas of the public service (OECD, 2008). ${ }^{6}$

Post-2008 civil and public service HR strategy documents again largely envisaged the retention of a career-based public service. Changes in the public service career system have prioritised meritbased promotion and greater cross-department and cross-publicservice mobility. At the same time civil and public servants aspiring to middle-and top-level posts now also face both public-service-wide competition and competition from outside the public service consistent with the espoused principle of 'opening up recruitment and promotion processes at all levels' (Department of Public Expenditure and Reform, 2014a, p. 20).

Competition to assistant principal and principal grades has become more open. Currently, more than two in three vacancies to the standard principal officer grade are filled through open competition (Department of Public Expenditure and Reform, 2019). From 2007, under the SMI, open competitions were held for appointments to assistant and deputy secretary positions. In 2010 a policy of open recruitment to secretary general and equivalent positions was adopted. In 2011 the membership of the Top Level Appointments Committee was changed to provide for a majority of external members, one of whom would be chair (Top Level Appointments Committee, 2013). A range of modern recruitment methods, such as

\footnotetext{
${ }^{5}$ Industrial Relations News, 29 March 2019.

${ }^{6}$ No systematic data were provided to illustrate the changes that had occurred in public service careers or the relative incidence of permanent and fixed-term employment contracts.
} 
executive search or 'head hunting', is also provided for in filling senior vacancies.

Numbers of applicants from outside the civil service have risen, the majority coming from the private sector. The incidence of appointments from outside departments filling posts has also increased (Top Level Appointments Committee, 2013, 2017). However, data on the professional backgrounds of those appointed to top-level civil service positions reveal little evidence of rising numbers from the wider public service or from outside the public service. The average incidence of recruitment to top positions from outside the public service between 2010 and 2016 was 11 per cent (Boyle, 2019, p. 24).

As outlined above, the 2008 OECD report was sharply critical of career silos in the civil and public service. Greater mobility over the course of careers across the civil and public service has been advocated and facilitated in post-2008 HRM reforms. This is a central objective of the Senior Public Service initiative, discussed below, and has also been given effect through protocols on mobility at principal officer level. A mobility scheme for other grades was also introduced on a phased basis from 2018, with a view to promoting mobility earlier in civil and public service careers.

A further significant development since 2011 has been the opening up of recruitment to non-civil servants. Initially, this was to enable the recruitment of what were deemed specialist skills; for example, in finance or economics. However, since the end of the recruitment embargo in 2014/15, open competitions have been held for all general service grades. As of the end of 2019, between a quarter and half of vacancies at general service grades are required to be filled through open competition (Department of Public Expenditure and Reform, 2019). With interdepartmental mobility also prominent, the objective has been to increase civil service capacity with roles being performed by those with the appropriate skills and experience.

The OECD (2012) categorised Ireland as a hybrid system, with elements of both career and position-based systems. In discussing the two approaches, the OECD concluded that both have their shortcomings. In general, recruitment systems that are open to external candidates at any point in their careers provide managers with the possibility to adjust their workforce more quickly in response to a changed environment. However, while these systems offer managers flexibility, they make it difficult to maintain cross-government values (OECD, 2012). 
The hierarchical character of civil service decision-making, underpinned by the system of grades, has also raised significant issues. Findings from the civil service engagement survey published in 2017 (DCU Business School and Department of Public Expenditure and Reform, 2017) found that the current hierarchical structure of the civil service poses challenges for effective communication across grades, inhibits innovation, acts as a demotivator, and is a hindrance to meeting challenges and optimising the potential talent of its current and future employees.

\section{Fostering leadership: The Senior Public Service}

While the SMI appeared to have envisaged the creation of a 'Senior Public Service' (SPS) (Murray, 2001), the 2008 OECD report primed the eventual creation of the SPS in 2011, a development that also mirrored practice in other European countries and beyond. Further impetus was added by the fiscal crisis and reform priorities that included the creation of greater leadership capacity across the public service (Senior Public Service, 2013, pp. 5-6). The SPS in the main comprises a development programme for civil servants at secretary general, deputy secretary, assistant secretary and director levels. Participation in SPS initiatives was extended to chief executives of non-commercial state agencies. The SPS is geared towards leadership development, succession planning and promoting mobility across the civil and public service. SPS initiatives include mentoring and executive coaching, training and development, $360^{\circ}$ performance feedback for professional development, the facilitation of mobility and the fostering of networking (Senior Public Service, 2017).

In 2019 an evaluation was conducted of the Executive Leadership Programme (ELP), which is a central component of the SPS (McCarthy, 2019). The NUI Galway evaluation study found that the ELP is highly regarded by programme participants and their line managers, and viewed as an effective leadership and talent development initiative. Key challenges identified included providing sufficient time to transfer learning, the balance between theory and practice, and the effectiveness and timing of coaching and mentoring.

\section{Strategic human resource management}

Promoting a more strategic approach to HRM, supported by proactive HR functions, had been a central objective of the SMI (PA Consulting 
Group, 2002, ch. 8). Certain basic features of a more strategic HRM (SHRM) architecture were developed in the civil service. Devolved administrative budgeting - which predated the SMI - allowed departments to configure their mix of grades up to and including the higher executive officer grade to align with their overall missions and strategies. Measures were undertaken to devolve responsibility for HR to line managers (Boyle, 1997; Murray, 2001). From 2004 recruitment and selection could also be devolved to departments, contingent on their competency to undertake this activity. PMDS and performancerelated pay allowed both work objectives and the development of competencies to be better aligned with departments' objectives and business plans. Notwithstanding these developments, reviews of HR pointed to significant limits on the capacity for SHRM in the civil service and public service agencies (PA Consulting, 2002, ch. 8). A study of six civil service departments that had been proactive in implementing HR activities under the SMI identified significant constraints on the development of SHRM. Extensive central regulation of HR practices remained, with limited devolution of HR to line managers. HR managers had limited professional training and often lacked the seniority to act as strategists (O'Riordan, 2004, ch. 4). A study of public service agencies revealed that very few possessed significant strategic HR autonomy; 70 per cent reported low or no HR autonomy (McGauran et al., 2005). A further study of organisational capacity in the civil service underlined a welter of shortcomings limiting the strategic management of human resources (O'Riordan, 2011). Reflecting these limitations, the major 2008 OECD assessment of the SMI concluded that little strategic coherence had been apparent in HR decisions made under the SMI (OECD, 2008, p. 116).

The centrality of SHRM to public service reform post 2008 has been emphasised in a succession of civil and public service reform and renewal documents. Some organisational changes introduced by DPER and geared to promoting SHRM were promising. In 2011 DPER established a HR strategy unit with both a departmental remit and a wider mission to develop more professional and strategic HR functions across the civil service. DPER's work on strategic HR included workforce planning and a learning and development strategy. The creation of shared HR services through the PeoplePoint platform, while not without problems, provided scope for HR officers to reduce their direct involvement in operational and transactional HR and to devote more time to 'business partnering' and other strategic HR roles. In 2015 a chief HR officer for the civil service was appointed to 
professionalise the management of HR and develop strategic HR (MacCarthaigh, 2017, pp. 229-31).

Against a backdrop of financial collapse, the government in 2008/9 sought to reduce public service numbers through incentivised early retirement and career break schemes, with departing staff not replaced. In late 2009 employment control frameworks (ECFs) were introduced in respect of each sector. These specified staffing reductions and in some cases the distribution of posts. A moratorium on the filling of vacancies by either recruitment or promotion was also put in place until the ECF was shown to be operating effectively in bringing about the reduction in staff numbers required. However, concerns were expressed at the loss of human capital as a result of this downsizing.

In order to support the process of workforce reduction, the government established strategic workforce planning groups in the civil service, education, health, local authority, defence and justice sectors. These workforce planning groups were intended 'to ensure that sectoral employers are developing plans to deal with the operational and strategic consequences arising from the anticipated staff turnover in 2012' (Howlin, 2012). While some organisations did subsequently engage with workforce planning, the overall picture for Ireland appears to be largely consistent with the conclusions of the $\operatorname{OECD}(2013$, p. 5) that 'many member countries continue to make little use of workforce planning'.

Our Public Service 2020 (Department of Public Expenditure and Reform, 2017b), the third public service reform plan, was published in late 2017. The priority actions identified in the area of 'developing our people and organisations' included embedding SHRM, strengthening performance management and mainstreaming strategic workforce planning. The overarching emphasis of the new plan was to build public service capacity to deliver better services to the public. Among the priority actions was mainstreaming strategic workforce planning in the public service. However, in research conducted for DPER, O'Riordan (2019) found that, with a small number of exceptions, there remained a weak understanding of the benefits of workforce planning and that efforts in this area were modest.

In an important commentary on public service management, the late professor John Murray (2007) highlighted the singular importance of 'public service capacity'. Capacity is about understanding the organisation's needs and effectively responding. This is predicated on strategic workforce planning, which supports the achievement of 
organisational objectives, meeting customer expectations, organisational governance, employee morale and the development of the workforce. The challenge is to ensure the widespread implementation of the practice across the public service.

\section{Employment relations}

The SMI's foundation document, Delivering Better Government, had little to say about public service employment relations or about pay fixing, other than endorsing the principle of pay for performance perhaps because proposals on pay would have been an employment relations and political hot potato. The significant change that occurred in public service pay fixing during the period of the SMI was the result of growing disorder in public service employment relations, spurred by wider developments in the economy and labour market. Pay disorder resulted from the view among public service unions and their members that pay increases for public servants were falling behind pay rises in the private sector as the economy recorded exceptional growth and reached near full employment. The immediate source of disorder lay in local bargaining increases gained by some public service unions that significantly exceeded the ceilings for local or grade-based awards agreed in prevailing social partnership programmes and that threatened to undermine the pay agreements. In response the government and public service unions agreed to establish the Public Service Benchmarking Body, which reported in 2002 and 2007. The first report resulted in pay increases averaging at 8.9 per cent, within a range of 3-25 per cent (Public Service Benchmarking Body, 2002).

The work of the benchmarking body was supported by a battalion of management consultants and involved a large-scale exercise in job evaluation and systematic pay comparisons between public and private sector jobs and grades. However, the resulting pay increases drew widespread media and political opprobrium and the view was widely reported that expediency and industrial muscle played a significant part in the pay increases awarded to different groups (Geary \& Murphy, 2011). The extreme opacity of the benchmarking methodology did little to quell this view. The more limited and modest pay rises awarded in the second round of pay benchmarking in 2007 where the value of public service pensions was factored into pay comparisons - did little to counter the persistence of widely voiced opposition to pay benchmarking as a sustainable model for public service pay fixing. This view was reinforced by research suggesting that 
a significant public service pay premium had opened over the private sector for many categories prior to the advent of the fiscal crisis and resulting pay cuts (Kelly et al., 2009).

As with pay fixing, the SMI was largely silent on reforms in public service industrial relations. Again, the reforms that were undertaken arose from wider developments: this time from the vogue in 'workplace partnership' from the late 1990s. As social partnership programmes from 1997 sought to gain support for cooperative partnership-based working across the economy, partnership structures were established in the civil service and across many areas of the wider public service (Roche \& Teague, 2014). Significantly, these workplace partnership arrangements were identified in social partnership agreements as a key delivery mechanism for public service modernisation reforms in general and for encompassing changes in work practices and aspects of HRM. In practice, however, workplace partnership seems to have been relegated to dealing with 'soft' and peripheral issues rather than mainstream business, and made little contribution to the public service modernisation and change programme (Roche \& Teague, 2014, pp. 3-4). Partnership working and associated arrangements mainly fell away during the fiscal crisis.

Relations with unions became more robust and arm's-length in character. The new rules of engagement between the parties proved highly effective when judged in terms of the delivery of the agreed reductions in the public service pay bill, reforms in work and organisational mobility, and other changes in work practices agreed in a succession of public service agreements from 2010, and outlined below. A striking feature of employment relations in the public service since 2008 has been the quantum of change that has been achieved with little attendant industrial conflict. In part this reflected the involvement of public service trade unions in the management of public service retrenchment. The agreements negotiated between the government and the public service unions also made provision for what in effect was mandatory arbitration of disputes over the terms of the agreements. Mandatory arbitration facilitated the implementation of agreed changes and provided for accelerated dispute resolution. Certainly, in areas of the public service, such as the HSE, the new dispute resolution procedure was hailed as a 'game-changer' (Teague et al., 2015, ch. 10).

If relations between managers and unions were productively robust across the public service, the civil service sought for the first time to foster and regularly monitor 'staff engagement'. Surveys conducted in 
2015 and 2017 revealed high and persisting levels of engagement, but also identified significant shortcomings in communications and staff involvement in decision-making. These shortcomings were attributed to the hierarchical nature of civil service organisations and their associated grades (DCU Business School and Department of Public Expenditure and Reform, 2017). New methods of communication and involvement that included 'town-hall meetings' were introduced to support the Civil Service Renewal Plan introduced in 2014.

Changes in public service pay and conditions introduced from 2009 were by and large intended as temporary measures contributing to fiscal consolidation. The 2010-2013 Croke Park and 2013-2016 Haddington Road Agreements involved public service unions in the managed contraction of the public services. These agreements involved concession bargaining: unions trading pay freezes, further pay cuts for higher earning public servants, additional working hours and changes in working practices for pledges of no compulsory job losses. The pay cuts and pension levy imposed in 2009, combined with further agreed pay cuts for higher earning public servants under the Haddington Road Agreement, resulted in cumulative salary reductions of between 7 and 21 per cent. Public service employment fell by 10 per cent to 2015 and the public service pay bill was cut by 12 per cent (Roche, 2016). Growing demand for public services was absorbed through agreed measures to promote mobility within and across workplaces and other changes in work practices. Weekly working hours were also increased by up to two hours under Haddington Road. Not all changes introduced post 2009 have been subject to joint agreement. From 2011 recruits to the public service were appointed on lower salary scales (resulting notoriously in 'twotier pay'). Career-average pensions were introduced for new entrants from 2013.

This historically remarkable series of changes ensued with little industrial conflict - though disputes with teachers' unions surrounding two-tier pay has smouldered on. Significant pay pressure built up, however, when the pay cuts were unravelled under the Lansdowne Road Agreement (2015-2018) and the Public Service Stability Agreement (2018-2020). A threatened strike by Gardaí in late 2016 challenged the phasing of pay restoration agreed under Lansdowne Road. The favourable Labour Court recommendation in the Garda dispute led to wider union demands for accelerated pay restoration and triggered negotiations in June 2017 leading to the Public Service Stability Agreement. This agreement in turn came under serious 
pressure in 2019 arising from disputes and work stoppages by nurses and healthcare assistants. As had previously occurred when the provisions of the Lansdowne Road Agreement were seen to have been breached, public service unions sought a review of the agreement, citing the Labour Court award that ended the nurses' dispute, fiscal recovery and pay increases conceded to workers in the private sector (Callinan, 2019). By mid 2019 a government minister was quoted as admitting that the public service pay deal was now 'being held together with sticky tape and blue tack'?

The pay review that arose from the contested process of pay restoration under the Lansdowne Road Agreement led to the innovative decision to establish the Public Service Pay Commission. The 2019 review of the public service stability agreements further resulted in dialogue on a longer-term sustainable system for determining pay in the public service.

The Public Service Pay Commission was established in 2016 in the wake of mounting pressure for accelerated pay restoration following the Garda settlement. The commission's brief was to advise the government on public service pay and problems surrounding recruitment and retention for certain groups of public servants, particularly in the health service. The commission was not seen as a substitute or replacement for collective bargaining. The commission's report, published in May 2017, presented econometric comparisons of public service and private sector pay levels, and appropriate international comparisons across public services, and took account of the state of the public finances (Public Service Pay Commission, 2017). The report effectively set the parameters informing negotiations leading to the Public Service Stability Agreement. The commission was less successful in steering the parties to sectional pay disputes towards agreed outcomes. In 2018 the commission examined a claim by nursing and midwifery unions for pay parity with other graduate health service professions. Pay increases for nurses and midwives were also viewed by their unions as warranted in the light of recruitment and retention problems in the professions. The report recommended enhanced allowances for some categories of nurses and midwives (Public Service Pay Commission, 2018, ch. 6). The nursing unions rejected the report and the Irish Nurses and Midwives Organisation engaged in a series of work stoppages in early 2019 and a Labour 
Court investigation. The court recommended a pay rise for nurses and midwives transferring to a new nursing grade - variously estimated as between 2 to 12 per cent. 8

The nurses' settlement led to immediate pressure for pay rises from other public service unions. As pressure built on the prevailing pay agreement, dialogue began on a new system of public service pay to be instituted in a successor agreement to the Public Service Stability Agreement on its expiry in 2020. By this point, following on from the public service pay freezes and reductions and increasingly widely prevalent annual pay rises in the private sector from 2011, public service pay levels overall were no longer higher than levels prevailing in the private sector, and were indeed lower towards the top of the pay range (Central Statistics Office, 2018). The ensuing talks made significant progress on the possible architecture of a new system for fixing public service pay. A new two-tier pay-fixing model was envisaged that would provide general pay rises for public servants and permit pay rises for categories or grades reflecting their circumstances and merits. ${ }^{9}$ These talks were paused for the general election in February 2020 and then overtaken by the Covid-19 crisis.

\section{Assessing HR reforms}

Notwithstanding its high-flown rhetoric and ambitious objectives, the SMI HR reform programme met with little success. The PMDS system had major shortcomings. Performance pay for senior public servants was, and remained, defective in major respects. The public service career-based system had become problematic, as position-based appointments were bolted on to a largely career-based system that was characterised by silos and limited mobility. SHRM amounted more to rhetoric than to reality. Workplace partnership had largely proven to be an ineffective channel for delivering reforms agreed under the social partnership programmes. Pay benchmarking was politically discredited.

To a significant degree the context in which SMI HR reforms were introduced contributed to the limited progress recorded. First, there was little political drive or impetus behind SMI reforms; the major champions of the SMI were senior public servants (Murray, 2001). The reform agenda never acquired political priority and little political

8 Industrial Relations News, 7 March 2019.

${ }^{9}$ Industrial Relations News, 28 November 2019. 
capital was expended in delivering reforms during the period. Second, the urgency of achieving reform was diluted by the economic growth and fiscal buoyancy of the period from the middle of the 1990s to 2008. Third, the designation of workplace partnership as a key mechanism for delivering reform may well have further reduced the impetus for change. Little evidence can be found that workplace partnership arrangements were effective in promoting public service reforms, while the combination of workplace partnership and established collective bargaining provided unions and their members with effective channels through which to delay or negate changes they found unpalatable. Furthermore there had been little oversight or rigorous assessment of the delivery of changes agreed under the social partnership agreements.

Changes made to HR during and after the fiscal crisis involved both areas of continuity with SMI reforms and some marked departures from the pre-crisis reform programme. The PMDS was retained and, despite ongoing design changes, reveals persisting problems. The aspiration for 'strategic HRM' has also been retained but with even greater emphasis and prominence. Some promising structural changes have been made to facilitate the emergence of SHRM, but progress has yet to be established and developments in the related area of strategic workforce planning remain weak. Public service careers continue to follow a mainly career-based model, but with more extensive provision for cross-public-service and external competition for posts at all levels. Progress in opening up the top levels of the civil service remains limited, when judged in terms of levels and trends in the professional backgrounds of appointees to top posts. More emphasis has also been given to fostering internal mobility to combat the career silos criticised in the 2008 OECD report. The creation of the Senior Public Service is a significant departure from past practice. While no assessment of the overall success of the programme has been undertaken, an evaluation of the associated ELP shows positive results.

In the area of employment relations and pay some developments have been remarkable - albeit that they were less outcomes of planned programmatic structural reforms than direct or indirect consequences of the crisis and subsequent recovery. The very sizeable reductions in the public service pay bill and associated changes in work practices that were achieved with little industrial conflict under the Croke Park and Haddington Road Agreements are notable achievements in contributing to fiscal consolidation and recovery - but at considerable 
cost to public servants. Developments in pay fixing with the potential for longer-term structural change arose out of joint efforts of public service employers and unions to manage pay restoration as fiscal and economic conditions improved. The Public Service Pay Commission and talks in 2019 and early 2020 on a public service pay model pointed the way towards a new pay-fixing model for the public service.

Post-crisis HR reforms and areas of contrast with SMI reforms need to be understood in the dramatically different context that pertained after 2008. The fiscal crisis injected a level of urgency into reforms and changes that had been absent in the more fiscally and economically benign context of the SMI. Further impetus was added by public service reform becoming for the first time a political priority, especially for the coalition government that came to power in 2011. The creation of DPER established a unitary champion and driver of reform that had again been absent under the SMI, where oversight was shared between the Department of the Taoiseach and the Department of Finance and political commitment was limited. Yet even these dramatic changes in context have not generated a complete disjuncture or transformation in public service HRM. When assessed against the reform objectives that have been articulated, major and abiding changes in core areas, such as performance management, open appointments to top-level positions, SHRM and workforce planning, remain elusive, while the search continues for an effective and sustainable pay-fixing model.

How can public service HR reforms in Ireland be portrayed in comparative terms? The SMI reform cycle of the period from the mid 1990s to 2008 reflected the international influence of the NPM paradigm of public service reform, particularly across AngloAmerican countries. An influential comparative analysis distinguished between 'laggards', 'modernisers' and 'marketisers' (Pollitt \& Bouckaert, 2000). Ireland during the SMI was portrayed by Murray (2001, pp. 6-8) as an 'active moderniser', committed to implementing reforms across all areas of public management, including HR. The OECD (2008) portrayed the direction of travel of Ireland's SMI programme in similar terms. The SMI also avoided imposing reforms top-down and was committed to seeking consensus for reforms with public service unions and professional bodies, following a reform pattern similar to small north-west European countries (Pollitt \& Bouckaert, 2000). Assessing the SMI in terms of the depth of reforms and achievement of reform objectives, other commentators portrayed Ireland as a 'comparative laggard' (MacCarthaigh \& Hardiman, 2020). 
Such a portrayal of the Irish case is more consistent with the assessment of SMI HR reforms presented in this paper.

In the wake of the fiscal crisis, a major comparative assessment of HR reform programmes in the EU distinguished between countries emphasising 'quantitative adjustment' measures focused on containing or reducing public service pay and numbers and those emphasising 'structural reforms', such as changes to pay and performance management systems, public service careers and other major areas of HR (Vaughan-Whitehead, 2013). Reforms in Ireland during the early years of the crisis were portrayed as primarily emphasising quantitative adjustment (Vaughan-Whitehead, 2013, ch. 1). However, as outlined above, as fiscal conditions stabilised and DPER set about a wider programme of HR reforms, structural changes became an increasingly prominent feature of the overall reform effort - albeit that many structural reforms involved a return to measures embarked upon under the SMI.

Reflecting international debate on the character of ongoing public service reforms (see Pollitt \& Bouckaert, 2017, ch. 1), some commentators have argued that reforms in Ireland after the fiscal crisis, including HR reforms, reflect a turn towards 'post-NPM' priorities (MacCarthaigh \& Hardiman, 2020, pp. 17-18). The key concerns of public service reform are seen to have included priorities that differ from and sometimes overturn NPM priorities: (re)centralising control over pay, conditions and headcount in place of NPM's emphasis on delegating these areas of HR to departments and agencies; greater attention to public-service-wide values and leadership in place of NPM's emphasis on aligning values and culture with the missions and objectives of departments and agencies; and a civil-service wide 'renewal project' focused on common reform measures. Other reform priorities seen to run counter to NPM include the consolidation of agencies and promotion of better policy coordination across government organisations (MacCarthaigh \& Hardiman, 2020, pp. 9-17).

The advent of the Covid-19 crisis and the emergence of a new coalition government in 2020 will also affect the pattern of ongoing and future public service reforms. The programme for government agreed between the coalition parties suggests that the direction of travel for public service management and reform will remain largely unchanged (Government of Ireland, 2020, pp. 121-2). The introduction of extensive home and remote working as a necessary consequence of the Covid-19 pandemic will likely lead to a permanent 
change in the numbers of people working in this way. The programme for government has set a target of 20 per cent home and remote working for public sector employers in 2021 (Government of Ireland, 2020, p. 121).

The government has launched a consultation process on home and remote working across the economy and DPER has been charged with developing a policy for the civil service. A survey of 3,860 public sector workers indicated that 8 out of 10 wished to continue working remotely to some degree (McCarthy, 2020). A survey of 4,300 mainly civil and public service workers conducted for the largest public service union, Fórsa, found that 86 per cent were interested in remote working, with most preferring hybrid home-workplace arrangements. A total of 70 per cent who had worked at home during the pandemic said that remote working had been a positive or very positive experience, with 50 per cent saying that remote working had improved their productivity (Fórsa, 2020).

Moves to normalise remote working in the public service will pose new challenges for a range of HR policies, including the HR role of line managers, performance management, career progression, work practices and organisation, and well-being, health and safety. With respect to relations with unions and pay fixing, the indications are that the direction of travel will largely remain the same as prior to the Covid-19 crisis. The new government seems intent on honouring the remaining pay increase of the Public Service Stability Agreement and on resuming negotiations with unions on a new architecture for public service pay fixing. A range of work practice flexibilities introduced during the Covid-19 crisis also seem likely to be on the agenda for negotiations with public service unions. ${ }^{10}$ The fiscal effects of the pandemic point to limited scope for short-term pay rises in a new public service pay agreement. The government's policy of responding to the economic effects of the pandemic through stimulus and reflation programmes means that pay cuts of the kind implemented during the post-2008 austerity period have not been mooted.

\section{Conclusions}

The challenges facing the Irish public service remain significant, with wide-ranging problems in areas such as health, housing and climate action - so-called 'wicked problems' requiring a 'joined-up' public- 
service-wide response. The Covid-19 pandemic, while taking these issues out of the news headlines, has at the same time further highlighted the priority of these key policy areas. It has also resulted in a deep economic downturn and a very uncertain economic and fiscal outlook (Central Bank of Ireland, 2020). In this context, good public management is more important than ever. This of course encompasses wide-ranging policy responses. However, progress in respect of the HRM priorities identified in this paper remains central to this effort.

\section{References}

Boyle, R. (1997). Civil service reform in the Republic of Ireland. Public Money and Management, 17, 49-53.

Boyle, R. (2014). Revisiting performance appraisal: Can the performance management and development system (PMDS) be made to work? [Tom O'Connor working paper series]. Cork: Department of Government, University College Cork.

Boyle, R. (2019). Public sector trends 2019. Dublin: Institute of Public Administration.

Callinan, K. (2019). The 'one size fits all' public service model: Is it fit for purpose? Address to IRN Conference, Dublin, March.

Cappelli, P., \& Tavis, A. (2016, October). The performance management revolution: The focus is shifting from accountability to learning. Harvard Business Review.

Central Bank of Ireland. (2020). Quarterly economic summary, July 32020. Retrieved from https://www.centralbank.ie/news/article/press-releaseQuarterlyBulletin32020-03-july-2020 [3 November 2020].

Central Statistics Office. (2018). Econometric analysis of the public-private sector pay differential 2018. Dublin: Central Statistics Office.

Civil Service Accountability Board. (2016). Annual report of the Civil Service Accountability Board. Dublin: Civil Service Accountability Board.

Comptroller and Auditor General. (2010). Report of the comptroller and auditor general: Volume 1. Dublin: Government Publications.

DCU Business School and Department of Public Expenditure and Reform. (2017). Shaping the future of work in the civil service in Ireland: Enriching involvement, innovation, performance, and citizen impact. Dublin: Government Publications.

Department of Finance. (2010a). PMDS staff evaluation survey report. Dublin: Department of Finance.

Department of Finance. (2010b). Strengthening the capacity of the department of finance: report of the independent panel. Dublin: Department of Finance. 
Department of Public Expenditure and Reform. (n.d.). Public service staff numbers databank. Retrieved from http://databank.per.gov.ie/Public_ Service_Numbers.aspx [15 September 2020].

Department of Public Expenditure and Reform. (2011). Public service reform plan. Dublin: Department of Public Expenditure and Reform.

Department of Public Expenditure and Reform. (2014a). The civil service renewal plan: $A$ vision and three-year action plan for the civil service. Dublin: Department of Public Expenditure and Reform.

Department of Public Expenditure and Reform. (2014b). Public service reform plan 2014-2016. Dublin: Department of Public Expenditure and Reform.

Department of Public Expenditure and Reform. (2016). Civil service management of underperformance policy. Circular DPE200-006-2016. Dublin: Department of Public Expenditure and Reform.

Department of Public Expenditure and Reform. (2017a). People strategy for the civil service 2017-2020. Dublin: Department of Public Expenditure and Reform.

Department of Public Expenditure and Reform. (2017b). Our public service 2020. Dublin: Department of Public Expenditure and Reform.

Department of Public Expenditure and Reform. (2019). Current sequence of promotion [unpublished]. Dublin: Department of Public Expenditure and Reform.

Fórsa. (2020). Largest ever employee survey reveals huge appetite for remote working. Retrieved from https://www.forsa.ie/largest-ever-employeesurvey-reveals-huge-appetite-for-remote-working/ [16 August 2020].

Geary, J., \& Murphy, A. (2011). The reform of public sector pay in Ireland under social pacts. In M. Baglioni \& B. Brandl (Eds), Labour relations: Between path dependency and global trends. Frankfurt: Peter Lang.

Government of Ireland. (1996). Delivering better government. Dublin: Government Publications.

Government of Ireland. (2020). Programme for government: Our shared future. Dublin: Government of Ireland.

Howlin, B. (2012). Reform of the public service. Administration, 60, 15-30.

Kelly, E., McGuinness, S., \& O’Connell, P. (2009). Benchmarking, social partnership and higher remuneration: Wage setting institutions and the public-private sector wage gap in Ireland. Economic and Social Review, 40, 339-70.

MacCarthaigh, M. (2017). Public sector reform in Ireland: Countering crisis. London: Palgrave Macmillan.

MacCarthaigh, M., \& Hardiman, N. (2020). Exploiting conditionality: EU and international actors in post-NPM reform in Ireland. Public Policy and Administration, 35 (2), 179-200.

McCarthy, A. (2019). SPS and PO executive leadership programme evaluation. Dublin: Department of Public Expenditure and Reform.

McCarthy, A. (2020). Public sector management: Responding to the crisis and beyond. Presentation to 'Public Services in Liminal Space', joint conference 
by the Irish Academy of Management and the British Academy of Management, Queen's University Belfast, 26 June.

McGauran, A. M., Verhoest, K., \& Humphreys, P. (2005). The corporate governance of agencies in Ireland. Dublin: Institute of Public Administration.

Mercer Human Resource Consulting. (2004). Evaluation of the PMDS in the civil service. Dublin: Mercer Human Resource Consulting.

Murphy, K. R. (2020). Performance evaluation will not die, but it should. Human Resource Management Journal, 30 (1), 13-31.

Murray, J. (2001). Reflections on the SMI [working paper]. Dublin: School of Business, Trinity College Dublin.

Murray, J. (2007). Building capacity. Retrieved from http://www.tara.tcd.ie/ bitstream/handle/2262/23939/IPA\%20Paper\%20 Murray\%2007. pdf? sequence $=1 \&$ isAllowed $=\mathrm{y}$ [10 June 2020].

OECD. (2008). Ireland: Towards an integrated public service. Paris: OECD.

OECD. (2012). Acquiring capacity. Paris: OECD.

OECD. (2013). The government workforce of the future: Innovation in strategic workforce planning in OECD countries [OECD working papers on public governance, no. 21] Paris: OECD.

O'Riordan, J. (2004). Developing a strategic approach to HR in the Irish public service [CPMR discussion paper, no. 26]. Dublin: Institute of Public Administration.

O'Riordan, J. (2011). Organisational capacity in the Irish civil service. [State of the public service research series, research paper no. 3]. Dublin: Institute of Public Administration.

O'Riordan J. (2019). Workforce planning in the Irish civil service. [State of the public service research series, research paper no. 24]. Dublin: Institute of Public Administration.

PA Consulting Group. (2002). Evaluation of the progress of the strategic management initiative/delivering better government modernisation programme. Dublin: PA Consulting Group.

Pollitt, C., \& Bouckaert, G. (2000). Public management reform. Oxford: Oxford University Press.

Pollitt, C., \& Bouckaert, G. (2017). Public management reform: A comparative analysis into the age of austerity (4th edn). Oxford: Oxford University Press.

Public Service Benchmarking Body. (2002). Report of the Public Service Benchmarking Body. Dublin: Government Publications.

Public Service Pay Commission. (2017). Report of the Public Service Pay Commission. Dublin: Public Service Pay Commission.

Public Service Pay Commission. (2018). Report of the Public Service Pay Commission, recruitment and retention, module 1. Dublin: Public Service Pay Commission.

Review Body on Higher Remuneration in the Public Sector. (2007). Report No. 42 to the Minister for Finance on the levels of remuneration appropriate to higher posts in the public sector. Dublin: Government Publications. 
Roche, W. K. (2016). Workplaces. In W. K. Roche, P. O'Connell, \& A. Prothero (Eds), Austerity and recovery in Ireland: Europe's poster child and the great recession. Oxford: Oxford University Press.

Roche, W. K., \& Teague, P. (2014). Effective but unappealing: Fifteen years of workplace partnership in Ireland. International Journal of Human Resource Management, 25, 781-94.

Senior Public Service. (2013). SPS leadership development strategy 2013-2015. Dublin: Senior Public Service.

Senior Public Service. (2017). SPS leadership development strategy 2017-2020. Dublin: Senior Public Service.

Teague, P., Roche, W. K., Gormley, T., \& Currie, D. (2015). Managing workplace conflict: Alternative dispute resolution in Ireland. Dublin: Institute of Public Administration.

Top-Level Appointments Committee. (2013). First report to the Minister for Public Expenditure and Reform. Dublin: Department of Public Expenditure and Reform.

Top-Level Appointments Committee. (2017). Fifth report to the Minister for Public Expenditure and Reform. Dublin: Department of Public Expenditure and Reform.

Vaughan-Whitehead, D. (2013). Public sector shock. London: Edward Elgar. 